\title{
An increase in cancer stem cell population after primary systemic therapy is a poor prognostic factor in breast cancer
}

\author{
HE Lee', JH Kim ${ }^{2,4}$, YJ Kim ${ }^{2,4}$, SY Choi ${ }^{2}$, S-W Kim ${ }^{3,4}$, E Kang ${ }^{4}$, IY Chung ${ }^{4}$, IA Kim ${ }^{4,5}$, EJ Kim ${ }^{6}$, Y Choi ${ }^{1,7}$, HS Ryu ${ }^{6}$ \\ and SY Park ${ }^{*, 6,7}$
}

'Department of Pathology, Seoul National University Hospital, 28 Yeongon-dong, Jongno-gu, Seoul I l 0-744, Korea; ${ }^{2}$ Department of Internal Medicine, Seoul National University College of Medicine, 28 Yeongon-dong, Jongno-gu, Seoul I l 0-799, Korea; ${ }^{3}$ Department of Surgery, Seoul National University College of Medicine, 28 Yeongon-dong, Jongno-gu, Seoul I l 0-799, Korea; ${ }^{4}$ Breast Care Center, Seoul National University Bundang Hospital,

300 Gumi-dong, Bundang-gu, Seongnam-si, Gyeonggi 463-707, Korea; ${ }^{5}$ Department of Radiation Oncology, Seoul National University College of Medicine, 28 Yeongon-dong, Jongno-gu, Seoul I I 0-799, Korea; ' ${ }^{6}$ Department of Pathology, Seoul National University Bundang Hospital, 300 Gumi-dong, Bundang-gu, Seongnam-si, Gyeonggi 463-707, Korea; ' Department of Pathology, Seoul National University College of Medicine, 28 Yeongon-dong, Jongno-gu, Seoul I 10-799, Korea

BACKGROUND: The cancer stem cell (CSC) hypothesis has important clinical implications for cancer therapeutics because of the proposed role of CSCs in chemoresistance. The aim of this study was to investigate changes in the CSC populations before and after primary systemic therapy (PST) and their prognostic role in human breast cancer.

METHODS: Paired samples (before and after PST) of breast cancer tissue were obtained from clinical stage $\|$ or III patients $(n=92)$ undergoing PST with the regimen of doxorubicin plus docetaxel (AD) $(n=50)$ or doxorubicin plus cyclophosphamide (AC) $(n=42)$ and subsequent breast resection. The proportions of putative CSCs with CD44 +/CD24- or aldehyde dehydrogenase I + $(\mathrm{ALDHI}+)$ phenotypes were determined by immunohistochemistry.

RESULTS: A higher proportion of CD44 + /CD24 - tumour cells and ALDHI positivity in pre-chemotherapy tissue was correlated with higher histologic grade, oestrogen receptor (ER) negativity, high Ki-67 proliferation index and basal-like subtype of breast cancer. Aldehyde dehydrogenase I positivity in pre-chemotherapy biopsy was also associated with a higher rate of pathologic complete response following PST. In comparisons of putative CSC populations before and after PST, the proportions of CD44 + /CD24- and $\mathrm{ALDHI}+$ tumour cells were significantly increased after PST. The cases with increased CD44 + /CD24- tumour cell populations after PST showed high Ki-67 proliferation index in post-chemotherapy specimens and those with increased ALDHI + tumour cell population after PST were associated with ER negativity and p53 overexpression. Furthermore, cases showing such an increase had significantly shorter disease-free survival time than those with no change or a reduced number of CSCs, and the survival difference was most notable with regard to the changes of ALDHI + tumour cell population in the patients who received AC regimen. CONCLUSION: The present study provides the clinical evidence that the putative CSCs in breast cancer are chemoresistant and are associated with tumour progression, emphasising the need for targeting of CSCs in the breast cancer therapeutics.

British Journal of Cancer (201 I) I 04, I730- 1738. doi:I0.1038/bjc.20 I I.I59 www.bjcancer.com

Published online 10 May 2011

(c) 20II Cancer Research UK

Keywords: breast cancer; cancer stem cells; primary systemic therapy; chemoresistance

Primary (neoadjuvant) systemic therapy (PST) is currently considered the standard care for locally advanced breast cancers (Buzdar, 2007; Gralow et al, 2008). Primary systemic therapy permits breast-conserving surgery and treats clinically undetectable micrometastatic disease before surgery. In addition, the degree of response to PST can be used as a prognostic indicator and pathologic complete response (pCR) is now recognised as an independent prognostic factor of patients with locally advanced breast cancer, who had received anthracycline-based or anthracycline- and taxane-based chemotherapy (Wolmark et al, 2001; Bear et al, 2006; Guarneri et al, 2006; Buzdar, 2007; Symmans et al, 2007; Chavez-MacGregor et al, 2010). On the other hand, drug resistance

*Correspondence: Dr SY Park; E-mail: sypmd@snu.ac.kr

Revised 5 April 20I I; accepted II April 20II; published online I0 May 2011 has become the major cause of treatment failure and is largely responsible for breast cancer mortality (Dean et al, 2005; Kakarala and Wicha, 2008; Morrison et al, 2008). Overcoming resistance to chemotherapeutic agents would represent a major advance in the clinical management of breast cancer.

There is accumulating evidence to support the cancer stem cell (CSC) hypothesis, which states that cancers are driven by a small population of stem cells that are capable of self-renewal and give rise to multipotent progenitor cells, and eventually, differentiate into all cell types within the tumour (Smalley and Ashworth, 2003; Clarke et al, 2006; Campbell and Polyak, 2007; Visvader and Lindeman, 2008; Nakshatri et al, 2009). Cancer stem cells may originate by malignant transformation of normal stem cells that have accumulated genetic and epigenetic modifications over time (Smalley and Ashworth, 2003; Dean et al, 2005; Visvader and Lindeman, 2008). Alternatively, they may arise from restricted 
progenitors of more differentiated cells that have acquired selfrenewing capacity through multiple genetic and epigenetic alterations (Smalley and Ashworth, 2003; Dean et al, 2005; Visvader and Lindeman, 2008).

Cancer stem cells were first identified in acute myeloid leukaemia (Lapidot et al, 1994), and recently, have also been documented in various solid tumours, including those of breast (Al-Hajj et al, 2003), brain (Singh et al, 2004), lung (Kim et al, 2005), colon (O'Brien et al, 2007), prostate (Collins et al, 2005) and pancreas (Li et al, 2007). In the case of breast tumours, Al-Hajj et al (2003) were the first to isolate a highly tumourigenic subpopulation of tumour cells with $\mathrm{CD} 44^{+} / \mathrm{CD} 24^{- \text {low }} /$ Lineage $^{-}$ phenotype. Subsequently, Ginestier et al (2007) presented evidence that aldehyde dehydrogenase 1 (ALDH1) is a marker of stem/ progenitor cells of the normal and malignant human breast. They demonstrated the tumourigenicity of ALDH1-positive cells by injection of ALDEFLUOR-positive population into NOD/SCID mice and detected ALDH1 expressing tumour cells in breast carcinoma tissue by immunohistochemistry. However, it is also known that none of these CSC markers is expressed exclusively by stem cells, and a considerable number of cells that express these markers are not stem cells, resulting in phenotypic heterogeneity within putative CSC populations (Clarke et al, 2006; Visvader and Lindeman, 2008).

The CSC hypothesis has important clinical implications for cancer therapeutics because of the suggested role of CSCs in chemoresistance (Kakarala and Wicha, 2008). There is increasing evidence that CSCs are naturally resistant to chemotherapy on account of their quiescence, more efficient DNA repair, resistance to apoptosis and expression of drug-resistance proteins, such as ATP-binding cassette transporters (ABCG2 and ABCG5) and multidrug-resistance protein 1 transporters (Dean et al, 2005). If this is correct, a small population of chemoresistant CSCs may resist killing by conventional chemotherapy, whereas majority of tumour cells, which are differentiated cells that lack 'stemness', may be killed. The tumour could, therefore, regrow after chemotherapy because of the capacity for self-renewal of these CSCs. However, there have been few reports of chemoresistance of CSCs in human breast tissue (Li et al, 2008; Tanei et al, 2009), although several in vitro studies have indicated it (Liu et al, 2006; Ghods et al, 2007; Yu et al, 2007; Fillmore and Kuperwasser, 2008).

The aim of this study was to investigate changes in CSC populations before and after PST and their prognostic role in human breast cancer. We determined the proportions of putative CSCs with CD44+/CD24- or ALDH1 + phenotypes using immunohistochemistry in pre- and post-chemotherapy breast cancer tissue, and analysed the association between the changes of putative CSC population after PST and clinicopathologic parameters, including patients' survival.

\section{PATIENTS AND METHODS}

\section{Patients and specimens}

Ninety-two patients with clinical stage II or III breast cancer (by AJCC 7th), who received surgical resection after PST in Seoul National University Bundang Hospital from May 2003 to February 2009 were enrolled. All patients were diagnosed to have invasive breast carcinoma by core needle biopsy, and were started on PST. Fifty patients were treated with doxorubicin plus docetaxel (AD) regimen containing $50 \mathrm{mg} \mathrm{m}^{-2}$ doxorubicin i.v. on day 1 and $75 \mathrm{mg} \mathrm{m}^{-2}$ docetaxel i.v. on day 1 every 3 weeks for three to six cycles (mean, five cycles). Forty-two patients received doxorubicin plus cyclophosphamide (AC) regimen containing $60 \mathrm{mg} \mathrm{m}^{-2}$ doxorubicin i.v. on day 1 and $600 \mathrm{mg} \mathrm{m}^{-2}$ cyclophosphamide i.v. on day 1 every 3 weeks for four cycles. Formalin-fixed and paraffin-embedded paired tissue samples of pre-chemotherapy biopsy and post-chemotherapy surgical resection were collected from each patient. None had received radiation therapy preoperatively. All were female, with a median age of 46 (range, 28-70). Clinicopathologic information was obtained by reviewing medical records, pathology reports and H\&E-stained sections. The following histopathologic variables were determined: histologic subtype, Bloom-Richardson histologic grade, $\mathrm{T}$ stage, $\mathrm{N}$ stage, oestrogen receptor (ER), progesterone receptor (PR), HER2 status, Ki-67 proliferation index and P53 expression. Pathological complete response following PST was defined as complete disappearance of all invasive cancer or only residual ductal carcinoma in situ. The duration of disease-free survival (DFS) was defined as the time between the start of PST and first recurrence/metastasis or death. All cases were independently reviewed by two breast pathologists (SYP and HEL). This study was approved by the Institutional Review Board of Seoul National University Bundang Hospital (protocol \# B-1008-110-301), waiving the requirement for informed consent for the study.

\section{Immunohistochemical staining}

Formalin-fixed and paraffin-embedded sections were dewaxed in xylene, rehydrated through graded alcohol and placed in an endogenous peroxide block for $15 \mathrm{~min}$. Antigen retrieval was carried out by microwave in $10 \mathrm{~mm}$ citrate buffer. Nonspecific staining was blocked by treating sections with $10 \%$ goat serum in phosphate-buffered saline ( $\mathrm{pH} 6.0$ ) for $10 \mathrm{~min}$. Immunohistochemical staining was carried out in a DAKO Autostainer Plus (Dako, Glostrup, Denmark) using an LSAB detection kit (Dako). The following primary antibodies were used: CD44 (1:200; clone 156-3C11; Neomarkers, Fremont, CA, USA), CD24 (1:100; clone SN3b; Neomarkers), ALDH1 (1:100; clone 44; BD Biosciences, Franklin Lakes, NJ, USA), cytokeratin 5/6 (CK5/6) (1:50; clone D5/16 B4; Dako) and epidermal growth factor receptor (EGFR) (EGFR pharmDx, Dako). The proportions of each antibodypositive tumour cells were counted semiquantitatively.

\section{Double immunohistochemical staining for CD44 and CD24}

Double immunostaining with antibodies to detect CD44 and CD24 was performed with EnVision G|2 Doublestain System Rabbit/ Mouse (diaminobenzidine $+(\mathrm{DAB}+) /$ Permanent Red) (Dako, Carpinteria, CA, USA) according to the manufacturer's instructions. CD44 was detected with DAB and CD24 with Permanent Red. We confirmed the accuracy of the double immunostaining by comparing it with single immunostaining for CD44 and CD24, separately. The proportions of CD44 + /CD24- tumour cells was counted semiquantitatively and scored in $5 \%$ increments.

\section{Breast cancer subtypes}

Although intrinsic subtypes of breast cancer were originally defined by gene expression profiling using DNA microarrays, most archival formalin-fixed paraffin-embedded samples are not amenable to cDNA microarray and subsequent studies revealed that subtypes can be accurately determined using immunohistochemical as a surrogate for molecular classification (Nielsen et al, 2004; Carey et al, 2006). Thus, breast cancer subtypes were defined as previously with minor modifications (Nielsen et al, 2004; Carey et al, 2006). Subtype definitions in this study were as follows: luminal A (ER + and/or PR,+ HER2-), luminal B (ER + and/or $\mathrm{PR}+$, HER $2+$ ), HER $2+(\mathrm{ER}-, \mathrm{PR}-$, HER $2+)$, basal-like (ER -, PR-, HER2-, CK5/6 + and/or EGFR +) and unclassified (negative for all markers).

With regard to immunostaining for ER and PR, cases with $10 \%$ or more positive staining were grouped as positive. Expression of EGFR and HER2 was scored as follows: 0 , no staining; $1+$, weak and incomplete membranous staining in $\geqslant 10 \%$ of the tumour 
cells; $2+$, weak to moderate, complete membranous staining in $\geqslant 10 \%$ of the tumour cells and $3+$, strong, complete membranous staining in $\geqslant 30 \%$ of the tumour cells. Any positive staining was regarded as positive for EGFR, and $3+$ on immunohistochemistry or presence of gene amplification on fluorescence in situ hybridisation was considered HER2 positive. For CK5/6, cases with any degree of positive staining were grouped as positive.

\section{Statistical analyses}

Non-continuous variables were compared using the $\chi^{2}$-test or Fisher's exact (two-sided) test and continuous variables using the Mann-Whitney $U$-test. Univariate and multivariate logistic regression models were used to identify predictive factors of pCR following PST. Changes of the CD44 + /CD24- and ALDH1 + tumour cell populations before $v s$ after PST were evaluated by Wilcoxon's signed-rank test. Survival curves were estimated using the Kaplan-Meier product-limit method, and the significances of differences between survival curves were determined using the logrank test. The covariates, which were statistically significant in the univariate analysis, were then included in the multivariate analysis using Cox proportional hazards regression model; the hazard ratio (HR) and its 95\% confidence interval (CI) were assessed for each factor. All statistical analyses were conducted using SPSS statistics 17.0 (SPSS Inc., Chicago, IL, USA), and $P$-values of $\leqslant 0.05$ were considered statistically significant.

\section{RESULTS}

Detection of CD44 + /CD24- and ALDH1 + tumour cells in pre-chemotherapy biopsy tissue

In 92 pre-chemotherapy biopsy tissues, median values of CD $44+1$ CD24- and ALDH1 + tumour cell proportions were 5\% (range, $0-95 \%)$ and $0 \%(0-80 \%)$, respectively. When ALDH1 immunostaining was classified into negative (ALDH1 + tumour cells $<5 \%$ ), $1+(\geqslant 5 \%,<10 \%),, 2+(\geqslant 10 \%,<50 \%)$ and $3+(>50 \%)$ groups, there were $80(87.0 \%), 3(3.3 \%), 8(8.7 \%)$ and $1(1.1 \%)$ cases assigned to the negative, $1+, 2+$ and $3+$ groups, respectively. We further classified the cases into negative $(<5 \%$; $n=80)$ and positive ( $\geqslant 5 \% ; n=12)$ groups for ALDH1 and found that the ALDH1-positive group contained a higher proportion of CD44+/CD24- tumour cells than the ALDH1-negative group (median (interquartile range), $45 \%(20-70 \%)$ vs 5\% (1-30\%); $P=0.003)$.

\section{Association between CD44+/CD24- and ALDH1 + tumour cell populations in pre-chemotherapy tissue and clinicopathologic characteristics}

We analysed the relationship between CD44/CD24 and ALDH1 expression status in pre-chemotherapy tissue and various clinicopathologic parameters. A higher proportion of CD44+/CD24tumour cells and ALDH1 positivity was associated with higher histologic grade $(P=0.002$ and $P=0.007$, respectively) and $E R$ negativity of tumour $(P<0.001$ and $P<0.001$, respectively). Neither clinical $\mathrm{T}$ nor clinical node stage was related to CD44/ CD24 or ALDH1 status. The differences in CD44 + /CD24- tumour cell proportions and ALDH1 positivity between the subtypes of breast cancer were statistically significant. Specifically, the basallike subtype had the highest proportion of CD44+/CD24tumour cells and the highest frequency of ALDH1 positivity among the subtypes. In addition, Ki-67 proliferation index was positively correlated with ALDH1 status $(P=0.020)$ (Table 1$)$. CD44/CD24 and ALDH1 expression status in pre-chemotherapy specimens was not associated with DFS (data not shown).
Table I Association between pre-chemotherapy CD44+/CD24tumour cell proportions and ALDHI positivity and clinicopathologic characteristics of the tumours

\begin{tabular}{|c|c|c|c|c|c|}
\hline \multirow[b]{2}{*}{ Characteristics } & \multicolumn{2}{|c|}{$\begin{array}{c}\text { CD44+/CD24- } \\
\text { tumour cell } \\
\text { population }\end{array}$} & \multicolumn{3}{|c|}{$\begin{array}{c}\text { ALDHI } \\
\text { expression } \\
\text { of tumour cells }\end{array}$} \\
\hline & $\begin{array}{l}\text { Median } \\
(\text { IQR) (\%) }\end{array}$ & $P$-value ${ }^{a}$ & $\begin{array}{l}\text { Negative } \\
\text { (no. (\%)) }\end{array}$ & $\begin{array}{l}\text { Positive } \\
\text { (no. (\%)) }\end{array}$ & $P$-value ${ }^{b}$ \\
\hline $\begin{array}{l}\text { cT stage } \\
\text { TI (2) and T2 (47) } \\
\text { T3 (30) } \\
\text { T4 (13) }\end{array}$ & $\begin{array}{r}5(1-42.5) \\
5(1-22.5) \\
45(5-77.5)\end{array}$ & 0.053 & $\begin{array}{l}40(50) \\
28(35) \\
12(15)\end{array}$ & $\begin{array}{l}9(75) \\
2(17) \\
1(8)\end{array}$ & 0.159 \\
\hline $\begin{array}{l}\text { cN stage } \\
\text { NO (I2) } \\
\mathrm{NI}-3(80)\end{array}$ & $\begin{aligned} 25 & (1-63.8) \\
5 & (1-40)\end{aligned}$ & 0.265 & $\begin{array}{l}11(14) \\
69(86)\end{array}$ & $\begin{aligned} & \mid(8) \\
\mid & (1(92)\end{aligned}$ & 1.000 \\
\hline $\begin{array}{l}\text { CTNM stage } \\
\|(4 I) \\
\text { III (5I) }\end{array}$ & $\begin{array}{r}5(1-35) \\
10(1-45)\end{array}$ & 0.288 & $\begin{array}{l}37(46) \\
43(54)\end{array}$ & $\begin{array}{l}4(33) \\
8(67)\end{array}$ & 0.538 \\
\hline $\begin{array}{l}\text { Histologic grade } \\
\text { Grade I (7) } \\
\text { Grade II (45) } \\
\text { Grade III (37) }\end{array}$ & $\begin{array}{r}5(1-50) \\
5(0-15) \\
20(5-65)\end{array}$ & 0.002 & $\begin{array}{c}7(9) \\
43(56) \\
27(35)\end{array}$ & $\begin{array}{c}0(0) \\
2(17) \\
10(83)\end{array}$ & 0.007 \\
\hline $\begin{array}{l}\text { Oestrogen receptor } \\
\text { Negative (35) } \\
\text { Positive (57) }\end{array}$ & $\begin{array}{r}20(5-65) \\
5(0-20)\end{array}$ & $<0.001$ & $\begin{array}{l}24(30) \\
56(70)\end{array}$ & $\begin{array}{l}\text { II }(92) \\
\text { I (8) }\end{array}$ & $<0.001$ \\
\hline $\begin{array}{l}\text { HER2 } \\
\quad \text { Negative (63) } \\
\text { Positive (29) }\end{array}$ & $\begin{array}{r}10(1-55) \\
5(1-15)\end{array}$ & 0.134 & $\begin{array}{l}54(68) \\
26(32)\end{array}$ & $\begin{array}{l}9(75) \\
3(25)\end{array}$ & 0.746 \\
\hline $\begin{array}{l}\text { Breast cancer subtype } \\
\text { Luminal A (40) } \\
\text { Luminal B (16) } \\
\text { HER2+ (13) } \\
\text { Basal-like (23) }\end{array}$ & $\begin{array}{l}5(0-35) \\
3.5(0-15) \\
10(1.5-20) \\
45(15-70)\end{array}$ & 0.001 & $\begin{array}{l}40(50) \\
15(19) \\
11(14) \\
14(17)\end{array}$ & $\begin{array}{l}0(0) \\
1(8) \\
2(17) \\
9(75)\end{array}$ & $<0.001$ \\
\hline $\begin{array}{l}\text { Ki-67 labelling index } \\
\quad \leqslant 20 \%(44) \\
>20 \%(48)\end{array}$ & $\begin{array}{c}5(0-35) \\
12.5(2-52.5)\end{array}$ & 0.064 & $\begin{array}{l}42(53) \\
38(47)\end{array}$ & $\begin{array}{r}2(17) \\
10(83)\end{array}$ & 0.020 \\
\hline $\begin{array}{l}\text { P53 staining } \\
\text { Negative (67) } \\
\text { Positive (25) }\end{array}$ & $\begin{array}{r}10(1-45) \\
2(1-15)\end{array}$ & 0.124 & $\begin{array}{l}58(73) \\
22(27)\end{array}$ & $\begin{array}{l}9(75) \\
3(25)\end{array}$ & 0.856 \\
\hline
\end{tabular}

Abbreviations: $\mathrm{ALDHI}=$ aldehyde dehydrogenase $\mathrm{I} ; \mathrm{cN}=$ clinical node; $\mathrm{cT}=$ clinical tumor; $c T N M=$ clinical tumor-node-metastasis; $H E R 2=$ human epidermal growth factor receptor 2; IQR = interquartile range. ${ }^{2}$ Mann-Whitney U-test or Kruskal -Wallis test. ${ }^{b} \chi^{2}$ or Fisher's exact test. IQR $(25-75 \%)$.

\section{CD44 + /CD24 - and ALDH1 + tumour cell population as a predictive factor of $\mathrm{pCR}$}

Thirteen $(13.7 \%)$ of the 92 patients, that is $5(10.0 \%)$ of 50 patients who were treated with $\mathrm{AD}$ regimen and $8(19.0 \%)$ of 42 patients who received AC regimen, achieved a PCR after PST and there was no statistical difference in pCR rate according to PST regimen. Aldehyde dehydrogenase 1 positivity of pre-chemotherapy tissue was significantly correlated with a higher rate of pCR after PST (10 vs 42\%; $P=0.003$; Figure 1B). This association was also found according to $\mathrm{PST}$ regimen (AD or $\mathrm{AC}$ regimen), although a statistical significance was reached only for $\mathrm{AD}$ regimen $(P=0.024)$ (Figures $1 \mathrm{D}$ and $\mathrm{F})$. The $\mathrm{pCR}$ group also showed a tendency to have a higher proportion of CD44 + /CD24- tumour cells than the non-pCR group not showing pCR in total patients $(P=0.262)$ and in the subgroup receiving $A C$ regimen $(P=0.130)$ (Figures $1 \mathrm{~A}, \mathrm{C}$ and $\mathrm{E}$ ).

To determine whether CD44 + /CD24- tumour cell proportion and ALDH1 positivity were predictive factors of pCR, we 
A

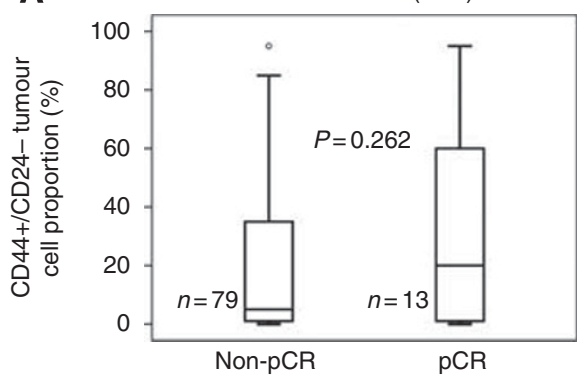

C

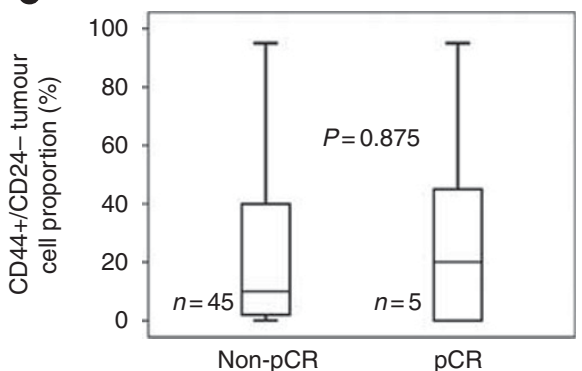

$\mathbf{E}$

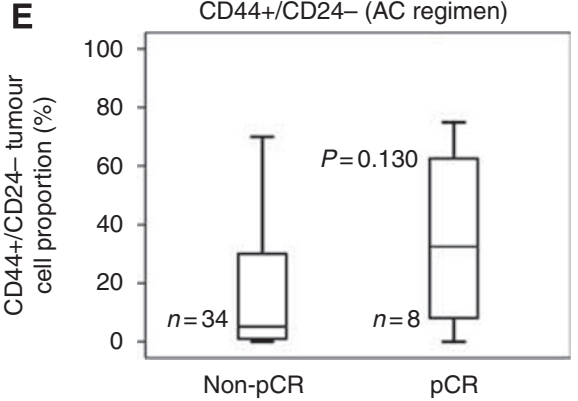

B

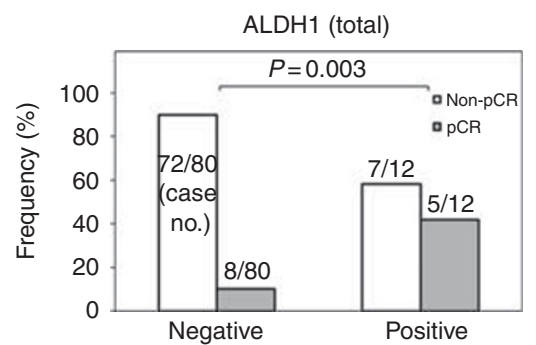

D

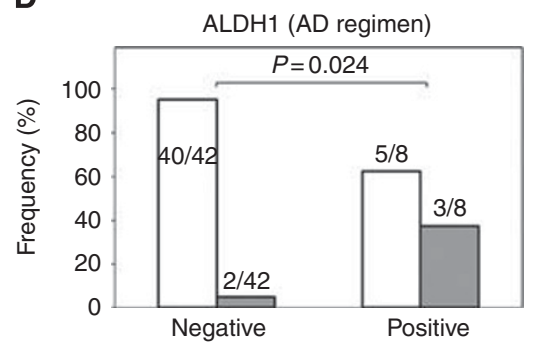

$\mathbf{F}$

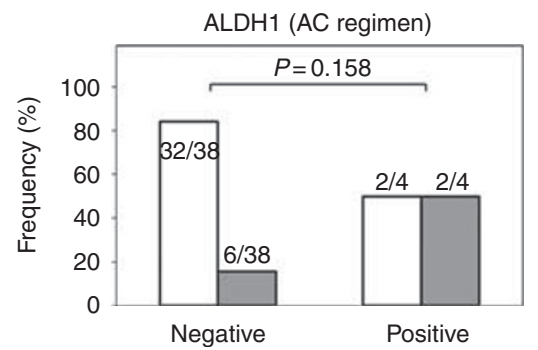

Figure I Association of CD44 + /CD24- and ALDHI + status with pathologic complete responses (pCR) following primary systemic therapy in total patients $(\mathbf{A}$ and $\mathbf{B})$ and in the subgroups by the primary systemic therapy regimen $(\mathbf{C}-\mathbf{F})$. The group showing pCR tended to have a higher proportion of CD44 + /CD24- tumour cells than the non-pCR group in total patients $(\mathbf{A})$ and in the subgroup treated with AC regimen $(\mathbf{E})$. The ALDHI positive group had a significantly higher likelihood of pCR than the ALDH-I-negative group in total $(\mathbf{B})$. This association was also found irrespective of primary systemic therapy regimen (AD or $A C$ regimen), although a statistical significance was reached only for $A D$ regimen $(\mathbf{D}$ and $\mathbf{F})$. $A D=$ doxorubicin plus docetaxel; $A C=$ doxorubicin plus cyclophosphamide.

Table 2 Univariate and multivariate logistic regression models for predictors of $\mathrm{pCR}$ following PST

\begin{tabular}{lcc}
\hline Variables & Odds ratio & $\mathbf{9 5 \%} \mathbf{C I}$ \\
\hline Univariate analysis & & $\mathbf{P}$-value \\
CD44+/CD24- tumour cell proportion (continuous) & 1.014 & $0.996-1.034$ \\
ALDHI positivity (negative vs positive) & 6.429 & $1.649-25.056$ \\
Histologic grade (grades I, II vs III) & 4.295 & $1.087-13.689$ \\
Oestrogen receptor (ER+ vs ER-) & 2.125 & $0.650-6.942$ \\
Breast cancer subtype (non basal-like vs basal-like) & 3.126 & $0.927-10.539$ \\
CT stage (cT3, 4 vs CTI, 2) & 3.419 & 0.007 \\
CN stage (cNI -3 vs CNO) & 1.255 & $0.879-13.367$ \\
PST regimen (AD vs AC) & 2.118 & $0.242-6.507$ \\
Multivariate analysis & & $0.636-7.051$ \\
ALDHI positivity (negative vs positive) & 4.150 & 0.067 \\
Histologic grade (grades I, II vs III) & 2.625 & 0.787 \\
\hline
\end{tabular}

Abbreviations: $\mathrm{AC}=$ doxorubicin plus cyclophosphamide; $\mathrm{AD}=$ doxorubicin plus docetaxel; $\mathrm{ALDHI}=$ aldehyde dehydrogenase $\mathrm{I} ; \mathrm{Cl}=\mathrm{confidence} \mathrm{interval;} \mathrm{CN}=$ clinical node; $\mathrm{cT}=$ clinical tumor; $\mathrm{pCR}=$ pathologic complete response; $\mathrm{PST}=$ primary systemic therapy.

performed logistic regression analyses. In univariate analysis, ALDH1 positivity and high histologic grade were found to be significantly associated with pCR ( $P=0.007$ and 0.037 , respectively). However, in multivariate analysis, they did not remain as independent predictive factors. CD44 + /CD24- tumour cell proportion was not a significant predictive factor of pCR (Table 2). 
A

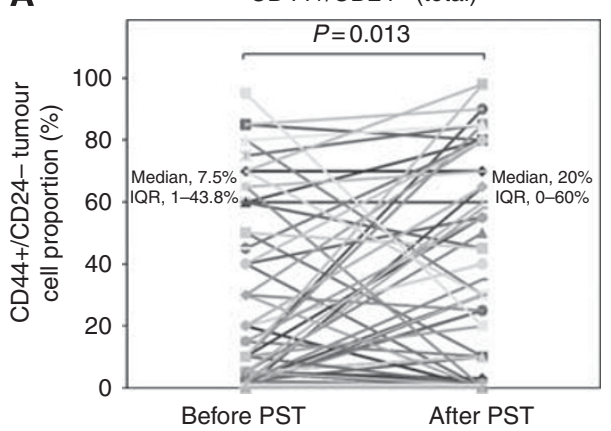

C

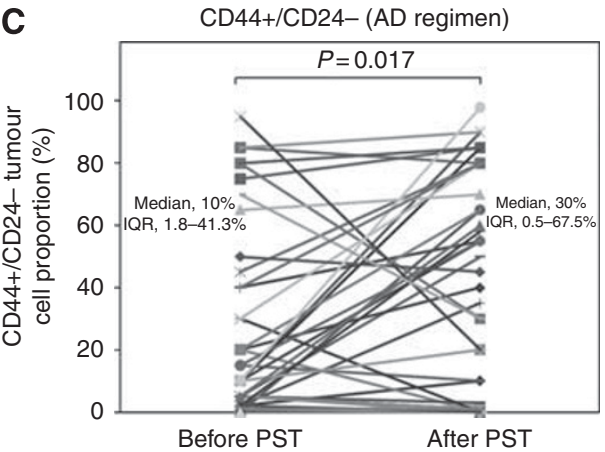

E

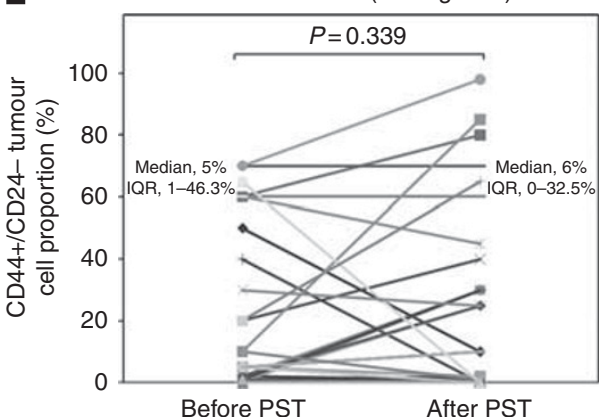

B

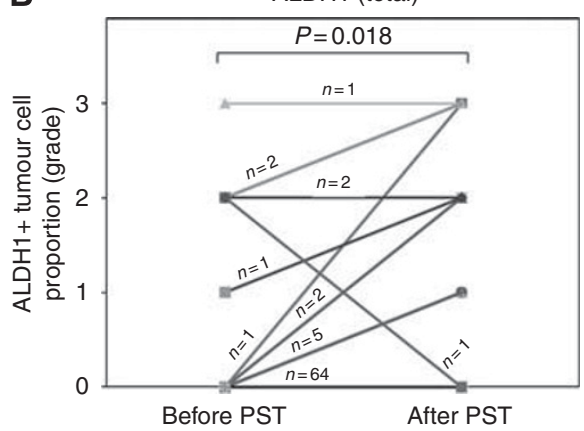

D

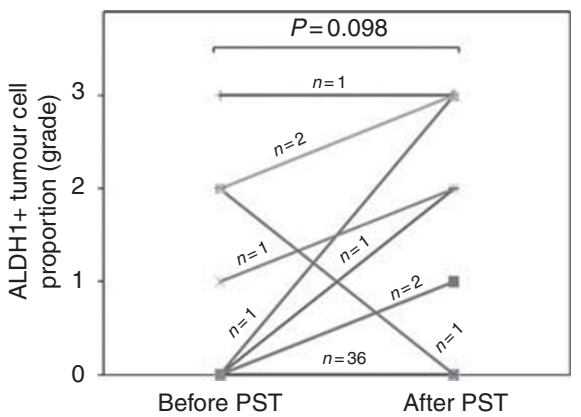

$\mathbf{F}$

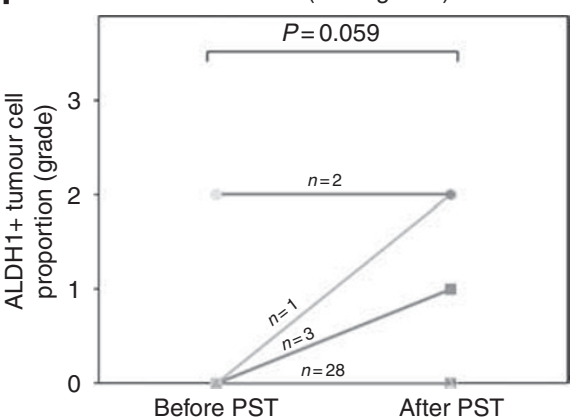

Figure 2 Changes of putative CSC populations after primary systemic therapy (PST) in the cases not achieving pathologic complete response. CD44 + I CD24- tumour cell proportions $(\mathbf{A})$ and ALDHI + tumour cell grades $(\mathbf{B})$ increased significantly after PST in total. Within the subgroup receiving AD regimen $(\mathbf{C}$ and $\mathbf{D})$, CD44 +/CD24- tumour cell proportions increased significantly $(\mathbf{C})$ and the grades of ALDHI + tumour cells showed a tendency to increase after PST $(\mathbf{D})$. In the subgroup treated with AC regimen $(\mathbf{E}$ and $\mathbf{F})$, only grades of ALDHI + tumour cells increased after PST with a marginal significance $(\mathbf{F})$. $A D=$ doxorubicin plus docetaxel; $A C=$ doxorubicin plus cyclophosphamide.

\section{Changes of CD44 + /CD24- and ALDH1 + tumour cell populations before and after PST and their relationships with DFS}

We assessed changes of CD44 +/CD24- and ALDH1 + tumour cell populations before and after PST in the 79 patients who did not achieve pCR. Both CD44 +/CD24- tumour cell proportions and grades of ALDH1 + tumour cells significantly increased after PST ( $P=0.013$ and $P=0.018$, respectively) (Figures 2A, B and 3). Within the subgroup receiving $\mathrm{AD}$ regimen, $\mathrm{CD} 44+/ \mathrm{CD} 24-$ tumour cell proportions also increased significantly $(P=0.017)$ and the grades of ALDH1 + tumour cells had a tendency to increase after PST $(P=0.098)$. In the subgroup treated with AC regimen, grades of ALDH1 + tumour cells increased after PST with a marginal significance $(P=0.059)$ (Figures $2 \mathrm{C}-\mathrm{F})$. Also, we investigated whether the changes of putative CSC population after PST varied according to breast cancer subtype. There were increasing trends of the putative CSC populations after PST regardless of the breast cancer subtype, and especially, grades of ALDH1 + tumour cells were significantly increased after PST in HER $2+$ subtype $(P=0.034)$ (Table 3$)$.
We analysed the association between the changes of CD44+I CD24- and ALDH1 + tumour cell population and clinicopathologic characteristics of tumour after PST. The cases with increased CD44 + /CD24- tumour cell populations after PST showed high Ki-67 proliferation index in post-chemotherapy specimens $(P=0.038)$ and tended to show high post-neoadjuvant therapy pathologic T $(y p T)$ stage $(P=0.091)$ and ER negativity $(P=0.067)$. The cases with increased ALDH1 + tumour cell population after PST were associated with ER negativity $(P=0.017)$ and p53 overexpression $(P=0.030)$ (Table 4$)$.

We also investigated the relationships of the changes of CD44 + /CD24- and ALDH1 + tumour cell population after PST with DFS. At the time of the analysis, the median follow-up was 3 years (range, 1-7 years). There were four (4\%) loco-regional recurrences as first events and seven (8\%) distant metastases. In Kaplan-Meier survival analyses, the patients with increased CD44 + /CD24- and ALDH1 + tumour cell populations had a significantly shorter DFS times than the remaining patients $(P=0.043$ and 0.041 , respectively) (Figures $4 \mathrm{~A}$ and $\mathrm{B})$. Subgroup analyses by the PST regimen revealed that the survival difference 

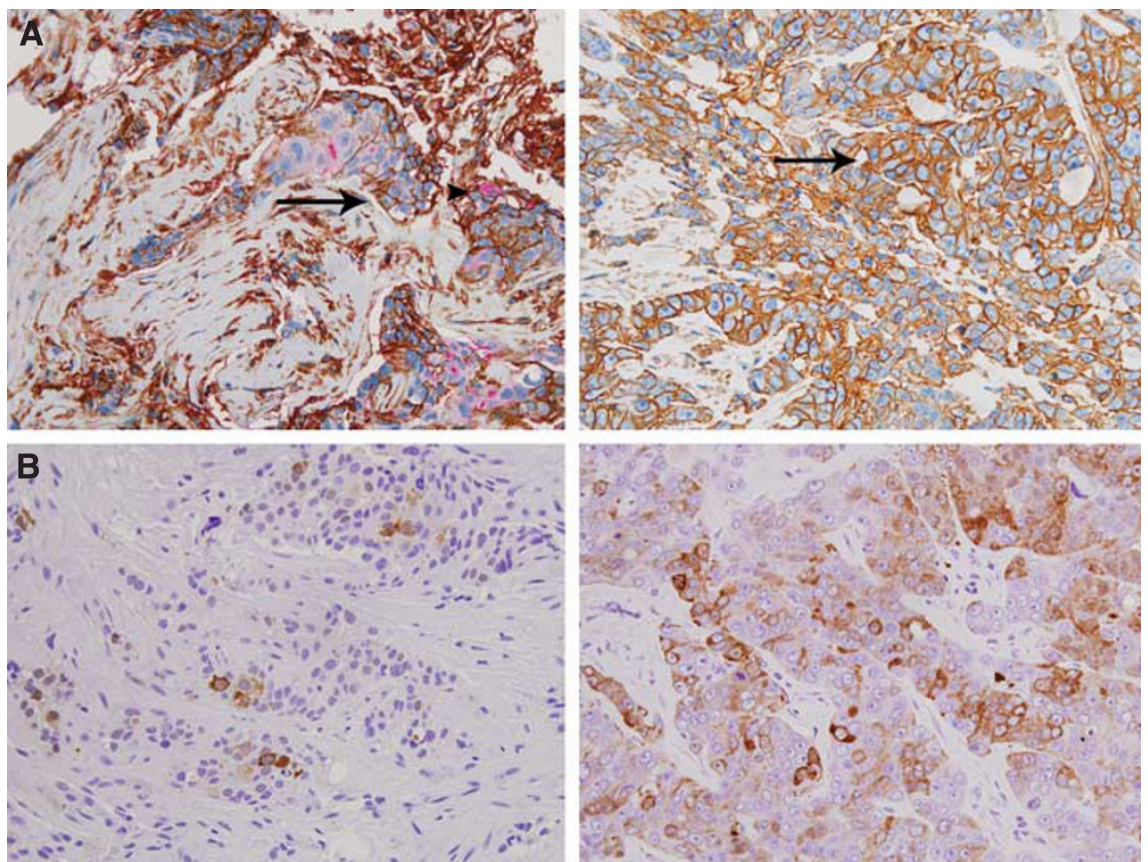

Figure 3 A representative example of the changes in putative CSC populations after primary systemic therapy. Both CD44+/CD24- (A) and $\mathrm{ALDHI}+(\mathbf{B})$ tumour cells were increased after PST in this case. An arrow head, a CD44+/CD24+ cell; arrows, CD44 + /CD24- cells (original magnifications, $\times 400)$

Table 3 Changes of putative CSC population before and after PST according to the breast cancer subtype in the cases not achieving PCR

\begin{tabular}{lcrc}
\hline Breast & $\begin{array}{c}\text { CD44+/CD24- } \\
\text { cancer } \\
\text { subtypes }\end{array}$ & $\begin{array}{c}\text { tumour cell proportion } \\
\text { (median (IQR), \%) }\end{array}$ & $\begin{array}{c}\text { Changes of ALDHI } \\
\text { grade (case no. with } \\
\text { increase/no change/ } \\
\text { decrease of ALDHI } \\
\text { grade after PST) }\end{array}$ \\
\cline { 2 - 3 } & Before PST & After PST & \\
\hline Luminal A $(n=38)$ & $5(0-35)$ & $6.5(0-47.5)$ & $2 / 36 / 0$ \\
Luminal B $(n=13)$ & $3.5(0-15)$ & $0(0-22.5)$ & $1 / 12 / 0$ \\
HER2+ $(n=11)$ & $10(1.5-20)$ & $40(0.5-70)$ & $5 / 6 / 0^{\mathrm{b}}$ \\
Basal-like $(n=17)$ & $45(15-70)$ & $55(20-80)$ & $3 / 13 / 1$ \\
\hline
\end{tabular}

Abbreviations: $\mathrm{ALDHI}=$ aldehyde dehydrogenase I: $\mathrm{CSC}=$ cancer stem cell: HER2 = human epidermal growth factor receptor $2 ; \mathrm{IQR}=$ interquartile range; $\mathrm{pCR}=$ pathologic complete response; PST $=$ primary systemic therapy. ${ }^{a}$ Wilcoxon's signed-rank test; ${ }^{\mathrm{b}} P=0.034$

was much greater in the patients receiving AC regimen between the group with increased ALDH + tumour cell population after PST and the remaining group $(P<0.001)$. On the other hand, there was no survival difference between the two groups in patients treated with $\mathrm{AD}$ regimen. With regard to the changes of $\mathrm{CD} 44+/ \mathrm{CD} 24-$ tumour cell populations, the patients with the increase of CD44+I CD24- tumour cell populations tended to have shorter DFS times than the remaining patients irrespective of PST regimen, although they were not statistically significant (Figures $4 \mathrm{C}-\mathrm{F}$ ). In multivariate analysis, ypT stage (ypT0-2 vs ypT3-4; HR, 4.82; 95\% CI: 1.28-18.18; $P=0.020$ ) was identified as an independent predictor for DFS. However, the changes of CD44 +/CD24- and ALDH1 + tumour cell populations did not remain as independent prognostic factors.

\section{DISCUSSION}

The present study showed that putative CSCs identified by CD44/ CD24 and ALDH1 immunohistochemistry significantly increased after PST in human breast cancer tissue. In addition, the cases with increased CD44 +/CD24- tumour cell populations after PST were found to have high Ki-67 proliferation index in post-chemotherapy specimens. More importantly, we report for the first time that the patients in whom the putative CSC population increased after PST had significantly shorter DFS times than patients in whom the putative CSC population were not changed or decreased. Furthermore, in the subgroup receiving $\mathrm{AC}$ regimen, the DFS time was much shorter in patients with increased ALDH + tumour cell population after PST than in the remaining patients. These findings indicate that putative CSCs with $\mathrm{CD} 44+/ \mathrm{CD} 24-$ or ALDH1 + phenotypes have an important role in chemoresistance to conventional $\mathrm{AD}$ and $\mathrm{AC}$ therapy and in disease progression.

There are several previous reports that CSCs contributes to chemoresistance in cancer therapeutics. However, most of them are in vitro studies (Liu et al, 2006; Ghods et al, 2007; Yu et al, 2007; Fillmore and Kuperwasser, 2008), and there are few reports showing an association between CSCs and chemoresistance in human breast cancer tissue. Some previous comparative studies using paired human breast cancer tissue obtained before and after chemotherapy found that CD44+/CD24- (Li et al, 2008) or ALDH1 + (Tanei et al, 2009) tumour cells increased significantly after chemotherapy, which is in agreement with our results. However, other workers detected no significant enrichment of ALDH1 + tumour cells (Resetkova et al, 2010) or even a reduction of CD44 + /CD24- tumour cells (Aulmann et al, 2010) after PST. The contradictory results could be explained as follows. First, the PST regimens and cycles differed in the various studies, and there may be treatment-specific influences on outcomes. Alternatively, differences in immunostaining methods and scoring protocols may have contributed to the discrepancies. In vivo studies using larger cohorts and more standardised methods will be required to settle the matter.

We characterised the putative CSC-rich breast cancer by assessing the relationship between CD44/CD24 or ALDH1 expression in pre-chemotherapy tissue and clinicopathologic parameters. In the current study, most of $\mathrm{CD} 44+/ \mathrm{CD} 24-$ or ALDH1 + cell-rich tumours belonged to the basal-like subtype, which accords with the several previous reports pointing to a relation between CSCs and the basal-like subtype (Honeth et al, 2008; Morimoto et al, 2009; Nalwoga et al, 2010; Park et al, 2010). These tumours displayed features of aggressive tumours, such as high 
Table 4 Association between the changes of putative CSC population after PST and clinicopathologic characteristics of the tumours in the postchemotherapy specimens

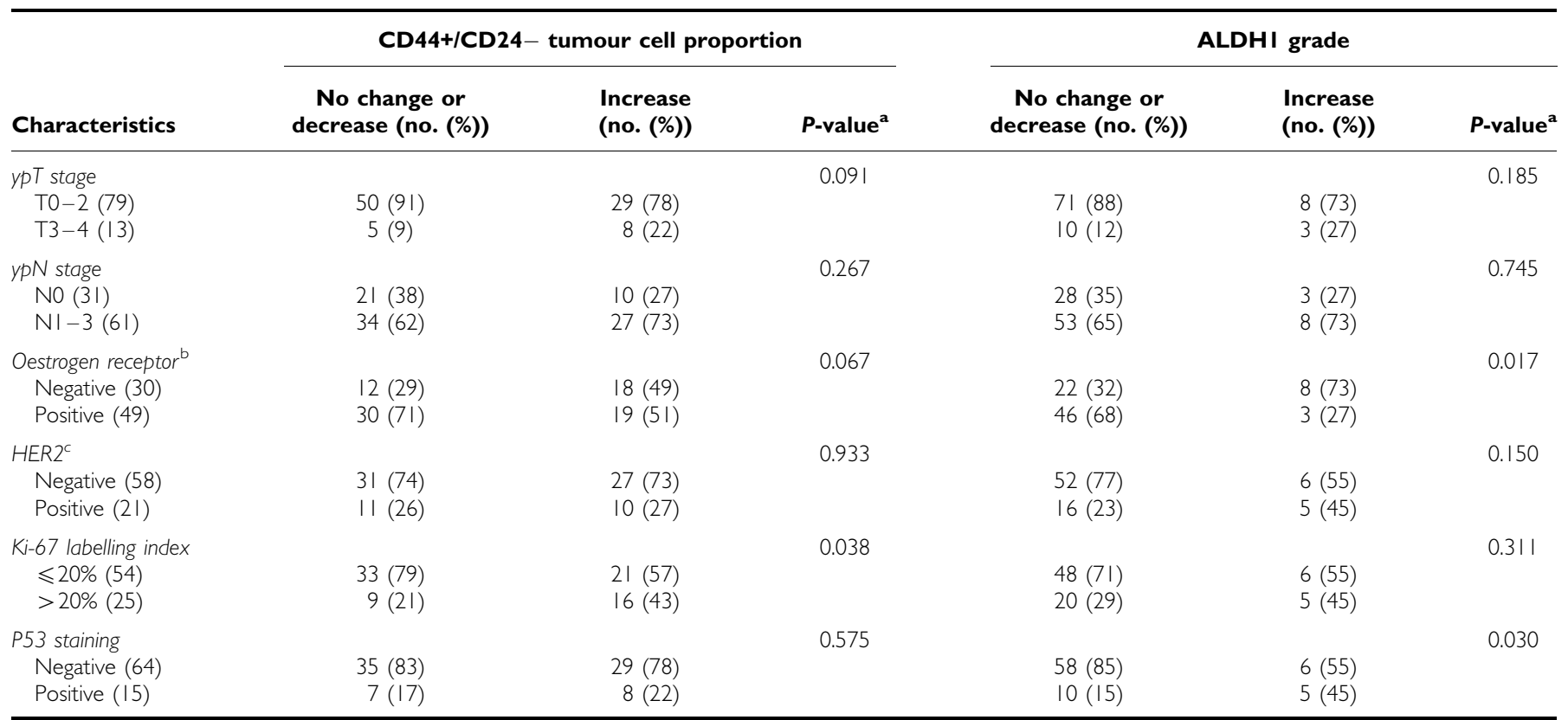

Abbreviations: $\mathrm{ALDHI}=$ aldehyde dehydrogenase I; CSC = cancer stem cell; HER2 = human epidermal growth factor receptor 2; PST = primary systemic therapy; yp $=$ postneoadjuvant therapy pathologic tumor; ypN = post-neoadjuvant therapy pathologic node. ${ }^{\mathrm{a}} \chi^{2}$ or Fisher's exact test. ${ }^{b} \mathrm{O}$ estrogen receptor status was changed from positive to negative after PST in two cases. 'HER2 status was converted from negative to positive after PST in a case.

histologic grade and high Ki-67 proliferation index, which are also characteristics of basal-like breast cancers as well.

With regard to the effect of CSC population size on patients' survival, there have been contradictory results. Whereas some studies failed to find a relationships between them (Abraham et al, 2005; Resetkova et al, 2010), others showed an inverse correlation (Ginestier et al, 2007; Morimoto et al, 2009; Charafe-Jauffret et al, 2010). In the present study, we found that increased CD $44+1$ CD24- and ALDH1 + tumour cell populations in post-chemotherapy specimen were prognostic factors for DFS, despite the fact that the size of the CD44+/CD24- or ALDH1 + tumour cell populations in pre-chemotherapy biopsy were not related to patients' survival. The CD44+/CD24- and ALDH1 + tumour cells in post-chemotherapy specimens may constitute more specific chemoresistant CSC populations than those in prechemotherapy specimens, and thus may have greater clinical significance. However, we cannot rule out the possibility that differentiated tumour cells acquire the CSC phenotype after chemotherapy due to selection pressure. In respect to breast cancer subtypes on patients' survival after PST, triple negative or basal-like breast cancers have been reported to show worse survival due to high relapse among those with residual disease after PST, despite higher chemosensitivity to conventional anthracyclin-based chemotherapy (so-called 'triple-negative paradox') (Carey et al, 2007; Bhargava et al, 2010). As basal-like tumours are enriched with CD44 +/CD24- or ALDH1 + tumour cell population, as shown in this study, one may expect that the cases with increased CSC population after PST were mostly chemoresistant basal-like subtype and thus, show wore prognosis. However, there were no differences in the number of cases with increased CSC populations according to subtype. And even if patients' survival was analysed only in the non-pCR group, we can find the tendency to have worse survival in cases with increased $\mathrm{CD} 44+/ \mathrm{CD} 24-$ or ALDH1 + tumour cell populations $(P=0.127$, 0.087, respectively; data not shown).

Although this study revealed prognostic significance of increased putative CSC population after PST in total, we failed to show its prognostic significance in the subgroup analyses according to PST regimen except for the changes of ALDH1 + tumour cell population in the subgroup receiving AC regimen. However, as our study was limited to a short follow-up period and a small number of cases, more extensive studies are needed to confirm the prognostic value of the CSC populations in post-chemotherapy specimens, especially, according to different chemotherapeutic regimens.

We found that ALDH1 positivity was significantly associated with the likelihood of pCR in breast cancer. Also, the group of patients showing pCR had a higher proportion of CD44 + /CD24tumour cells than those not showing pCR, although the difference was not statistically significant. These observations would seem to indicate that CSCs are chemosensitive, which appears to contradict our suggestion that they have a key role in chemoresistance. However, if cellular heterogeneity exist within the CSC populations detected by the putative breast CSC markers, all the CD $44+1$ CD24- and ALDH1 + tumour cells would not necessarily be CSCs. Accordingly, those that were easily killed by PST in this study are not likely to be CSCs per se, but rather transit amplifying cells. Other important points to note are that breast cancers that have high histologic grades, are ER negative and have high Ki-67 proliferation indices, are prone to achieve pCR following PST, as demonstrated in many previous studies (Ellis et al, 1998; Chang et al, 1999; Rouzier et al, 2005; Carey et al, 2007) and that ER-negative cancers, especially basal-like breast cancers, are enriched in CSCs (Honeth et al, 2008; Morimoto et al, 2009; Nalwoga et al, 2010; Park et al, 2010). Taken together, the reason why tumours with high CD44+/CD24- and ALDH1 + cell populations tend to achieve $\mathrm{PCR}$ may be related to their possession of pathologic features predictive of pCR (high histologic grade, ER negativity and high Ki-67 proliferation index, etc.), rather than with their stem cell properties.

The CSC hypothesis has important clinical implications for early detection, prevention and treatment of breast cancer. On the basis of that hypothesis, clinical trials are now being initiated that use drugs targeting CSCs or CSC-regulatory molecules, such as $\gamma$ secretase inhibitors that are able to inhibit Notch signalling and inhibitors of hedgehog signalling (Kakarala and Wicha, 2008). Our observation of 

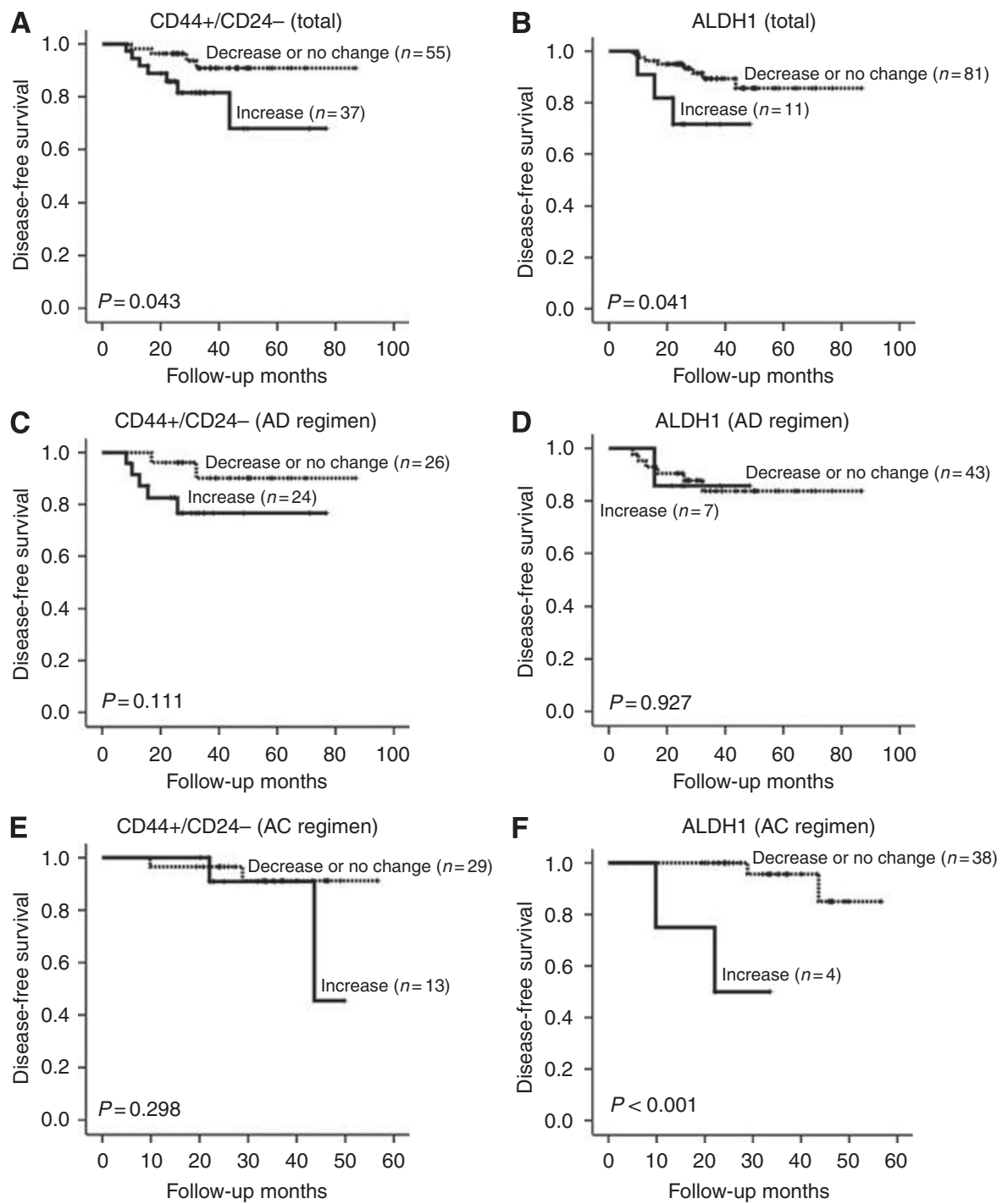

Figure 4 Disease-free survivals according to changes of the putative CSC population after primary systemic therapy. Patients with increased proportions of CD44 + /CD24- (A) and ALDHI + (B) tumour cells showed significantly poorer DFS than the other patients in total. In the subgroup analyses by primary systemic therapy (PST) regimen (AD or AC regimen), the patients with the increase of CD44 + /CD24- tumour cell populations tended to have shorter DFS times than the remaining patients irrespective of PST regimen $(\mathbf{C}$ and $\mathbf{E})$. With regard to the changes of ALDHI + tumour cell populations in the subgroup analyses by PST regimen ( $\mathbf{D}$ and $\mathbf{F})$, the survival difference was much greater in the subgroup receiving $A C$ regimen $(\mathbf{F})$, but not in the subgroup treated by $A D$ regimen $(\mathbf{D})$. $A D=$ doxorubicin plus docetaxel; $A C=$ doxorubicin plus cyclophosphamide.

the association between CSCs and chemoresistance in the present study underlines the importance of targeting therapy to CSCs.

In conclusion, the present study indicates the chemoresistant property of putative CSCs to the conventional anthracyclin-based chemotherapy and their role in disease progression by demonstrating an increase in the proportion of CSCs after PST and their association with reduced DFS. These findings emphasise the need to target CSCs in breast cancer treatment. We also suggest that the breast CSC population detected by CD44/CD24 or ALDH1

\section{REFERENCES}

Abraham BK, Fritz P, McClellan M, Hauptvogel P, Athelogou M, Brauch H (2005) Prevalence of CD44+/CD24-/low cells in breast cancer may not be associated with clinical outcome but may favor distant metastasis. Clin Cancer Res 11: 1154-1159

Al-Hajj M, Wicha MS, Benito-Hernandez A, Morrison SJ, Clarke MF (2003) Prospective identification of tumorigenic breast cancer cells. Proc Natl Acad Sci USA 100: 3983-3988 expression is heterogeneous and hence that validation of these CSC markers and the development of the more definitive markers would be important.

\section{ACKNOWLEDGEMENTS}

This study was supported by Grant no. 11-2009-026 from the Seoul National University Bundang Hospital Research Fund. 
cyclophosphamide for operable breast cancer: National Surgical Adjuvant Breast and Bowel Project Protocol B-27. J Clin Oncol 24: 2019-2027

Bhargava R, Beriwal S, Dabbs DJ, Ozbek U, Soran A, Johnson RR, Brufsky AM, Lembersky BC, Ahrendt GM (2010) Immunohistochemical surrogate markers of breast cancer molecular classes predicts response to neoadjuvant chemotherapy: a single institutional experience with 359 cases. Cancer 16: $4131-4139$

Buzdar AU (2007) Preoperative chemotherapy treatment of breast cancer-a review. Cancer 110: 2394-2407

Campbell LL, Polyak K (2007) Breast tumor heterogeneity: cancer stem cells or clonal evolution? Cell Cycle 6: $2332-2338$

Carey LA, Dees EC, Sawyer L, Gatti L, Moore DT, Collichio F, Ollila DW, Sartor CI, Graham ML, Perou CM (2007) The triple negative paradox: primary tumor chemosensitivity of breast cancer subtypes. Clin Cancer Res 13: $2329-2334$

Carey LA, Perou CM, Livasy CA, Dressler LG, Cowan D, Conway K, Karaca G, Troester MA, Tse CK, Edmiston S, Deming SL, Geradts J, Cheang MC, Nielsen TO, Moorman PG, Earp HS, Millikan RC (2006) Race, breast cancer subtypes, and survival in the Carolina Breast Cancer Study. JAMA 295: 2492-2502

Chang J, Powles TJ, Allred DC, Ashley SE, Clark GM, Makris A, Assersohn L, Gregory RK, Osborne CK, Dowsett M (1999) Biologic markers as predictors of clinical outcome from systemic therapy for primary operable breast cancer. J Clin Oncol 17: 3058-3063

Charafe-Jauffret E, Ginestier C, Iovino F, Tarpin C, Diebel M, Esterni B, Houvenaeghel G, Extra JM, Bertucci F, Jacquemier J, Xerri L, Dontu G, Stassi G, Xiao Y, Barsky SH, Birnbaum D, Viens P, Wicha MS (2010) Aldehyde dehydrogenase 1-positive cancer stem cells mediate metastasis and poor clinical outcome in inflammatory breast cancer. Clin Cancer Res 16: $45-55$

Chavez-Macgregor M, Litton J, Chen H, Giordano SH, Hudis CA, Wolff AC, Valero V, Hortobagyi GN, Bondy ML, Gonzalez-Angulo AM (2010) Pathologic complete response in breast cancer patients receiving anthracycline- and taxane-based neoadjuvant chemotherapy: evaluating the effect of race/ethnicity. Cancer 116: $4168-4177$

Clarke MF, Dick JE, Dirks PB, Eaves CJ, Jamieson CH, Jones DL, Visvader J, Weissman IL, Wahl GM (2006) Cancer stem cells-perspectives on current status and future directions: AACR Workshop on cancer stem cells. Cancer Res 66: 9339-9344

Collins AT, Berry PA, Hyde C, Stower MJ, Maitland NJ (2005) Prospective identification of tumorigenic prostate cancer stem cells. Cancer Res 65: $10946-10951$

Dean M, Fojo T, Bates S (2005) Tumour stem cells and drug resistance. Nat Rev Cancer 5: 275-284

Ellis P, Smith I, Ashley S, Walsh G, Ebbs S, Baum M, Sacks N, McKinna J (1998) Clinical prognostic and predictive factors for primary chemotherapy in operable breast cancer. J Clin Oncol 16: 107-114

Fillmore CM, Kuperwasser C (2008) Human breast cancer cell lines contain stem-like cells that self-renew, give rise to phenotypically diverse progeny and survive chemotherapy. Breast Cancer Res 10: R25

Ghods AJ, Irvin D, Liu G, Yuan X, Abdulkadir IR, Tunici P, Konda B, Wachsmann-Hogiu S, Black KL, Yu JS (2007) Spheres isolated from 9L gliosarcoma rat cell line possess chemoresistant and aggressive cancer stem-like cells. Stem Cells 25: 1645-1653

Ginestier C, Hur MH, Charafe-Jauffret E, Monville F, Dutcher J, Brown M, Jacquemier J, Viens P, Kleer CG, Liu S, Schott A, Hayes D, Birnbaum D, Wicha MS, Dontu G (2007) ALDH1 is a marker of normal and malignant human mammary stem cells and a predictor of poor clinical outcome. Cell Stem Cell 1: 555-567

Gralow JR, Burstein HJ, Wood W, Hortobagyi GN, Gianni L, von Minckwitz G, Buzdar AU, Smith IE, Symmans WF, Singh B, Winer EP (2008) Preoperative therapy in invasive breast cancer: pathologic assessment and systemic therapy issues in operable disease. J Clin Oncol 26: $814-819$

Guarneri V, Broglio K, Kau SW, Cristofanilli M, Buzdar AU, Valero V, Buchholz T, Meric F, Middleton L, Hortobagyi GN, Gonzalez-Angulo AM (2006) Prognostic value of pathologic complete response after primary chemotherapy in relation to hormone receptor status and other factors. J Clin Oncol 24: 1037-1044

Honeth G, Bendahl PO, Ringner M, Saal LH, Gruvberger-Saal SK, Lovgren K, Grabau D, Ferno M, Borg A, Hegardt C (2008) The CD44+/CD24- phenotype is enriched in basal-like breast tumors. Breast Cancer Res 10: R53

Kakarala M, Wicha MS (2008) Implications of the cancer stem-cell hypothesis for breast cancer prevention and therapy. J Clin Oncol 26: $2813-2820$
Kim CF, Jackson EL, Woolfenden AE, Lawrence S, Babar I, Vogel S, Crowley D, Bronson RT, Jacks T (2005) Identification of bronchioalveolar stem cells in normal lung and lung cancer. Cell 121: 823-835

Lapidot T, Sirard C, Vormoor J, Murdoch B, Hoang T, Caceres-Cortes J, Minden M, Paterson B, Caligiuri MA, Dick JE (1994) A cell initiating human acute myeloid leukaemia after transplantation into SCID mice. Nature 367: 645-648

Li C, Heidt DG, Dalerba P, Burant CF, Zhang L, Adsay V, Wicha M, Clarke MF, Simeone DM (2007) Identification of pancreatic cancer stem cells. Cancer Res 67: $1030-1037$

Li X, Lewis MT, Huang J, Gutierrez C, Osborne CK, Wu MF, Hilsenbeck SG, Pavlick A, Zhang X, Chamness GC, Wong H, Rosen J, Chang JC (2008) Intrinsic resistance of tumorigenic breast cancer cells to chemotherapy. J Natl Cancer Inst 100: 672-679

Liu G, Yuan X, Zeng Z, Tunici P, Ng H, Abdulkadir IR, Lu L, Irvin D, Black KL, Yu JS (2006) Analysis of gene expression and chemoresistance of CD133+ cancer stem cells in glioblastoma. Mol Cancer 5: 67

Morimoto K, Kim SJ, Tanei T, Shimazu K, Tanji Y, Taguchi T, Tamaki Y, Terada N, Noguchi S (2009) Stem cell marker aldehyde dehydrogenase 1-positive breast cancers are characterized by negative estrogen receptor, positive human epidermal growth factor receptor type 2, and high Ki67 expression. Cancer Sci 100: $1062-1068$

Morrison BJ, Schmidt CW, Lakhani SR, Reynolds BA, Lopez JA (2008) Breast cancer stem cells: implications for therapy of breast cancer. Breast Cancer Res 10: 210

Nakshatri H, Srour EF, Badve S (2009) Breast cancer stem cells and intrinsic subtypes controversies rage on. Curr Stem Cell Res Ther 4: 50-60

Nalwoga H, Arnes JB, Wabinga H, Akslen LA (2010) Expression of aldehyde dehydrogenase 1 (ALDH1) is associated with basal-like markers and features of aggressive tumours in African breast cancer. Br J Cancer 102: $369-375$

Nielsen TO, Hsu FD, Jensen K, Cheang M, Karaca G, Hu Z, HernandezBoussard T, Livasy C, Cowan D, Dressler L, Akslen LA, Ragaz J, Gown AM, Gilks CB, van de Rijn M, Perou CM (2004) Immunohistochemical and clinical characterization of the basal-like subtype of invasive breast carcinoma. Clin Cancer Res 10: 5367-5374

O'Brien CA, Pollett A, Gallinger S, Dick JE (2007) A human colon cancer cell capable of initiating tumour growth in immunodeficient mice. Nature 445: $106-110$

Park SY, Lee HE, Li H, Shipitsin M, Gelman R, Polyak K (2010) Heterogeneity for stem cell-related markers according to tumor subtype and histologic stage in breast cancer. Clin Cancer Res 16: 876-887

Resetkova E, Reis-Filho JS, Jain RK, Mehta R, Thorat MA, Nakshatri H, Badve S (2010) Prognostic impact of ALDH1 in breast cancer: a story of stem cells and tumor microenvironment. Breast Cancer Res Treat 123: 97-108

Rouzier R, Pusztai L, Delaloge S, Gonzalez-Angulo AM, Andre F, Hess KR, Buzdar AU, Garbay JR, Spielmann M, Mathieu MC, Symmans WF, Wagner P, Atallah D, Valero V, Berry DA, Hortobagyi GN (2005) Nomograms to predict pathologic complete response and metastasis-free survival after preoperative chemotherapy for breast cancer. J Clin Oncol 23: $8331-8339$

Singh SK, Hawkins C, Clarke ID, Squire JA, Bayani J, Hide T, Henkelman RM, Cusimano MD, Dirks PB (2004) Identification of human brain tumour initiating cells. Nature 432: 396-401

Smalley M, Ashworth A (2003) Stem cells and breast cancer: a field in transit. Nat Rev Cancer 3: 832-844

Symmans WF, Peintinger F, Hatzis C, Rajan R, Kuerer H, Valero V, Assad L, Poniecka A, Hennessy B, Green M, Buzdar AU, Singletary SE, Hortobagyi GN, Pusztai L (2007) Measurement of residual breast cancer burden to predict survival after neoadjuvant chemotherapy. J Clin Oncol 25: $4414-4422$

Tanei T, Morimoto K, Shimazu K, Kim SJ, Tanji Y, Taguchi T, Tamaki Y, Noguchi S (2009) Association of breast cancer stem cells identified by aldehyde dehydrogenase 1 expression with resistance to sequential Paclitaxel and epirubicin-based chemotherapy for breast cancers. Clin Cancer Res 15: 4234-4241

Visvader JE, Lindeman GJ (2008) Cancer stem cells in solid tumours: accumulating evidence and unresolved questions. Nat Rev Cancer 8: 755 - 768

Wolmark N, Wang J, Mamounas E, Bryant J, Fisher B (2001) Preoperative chemotherapy in patients with operable breast cancer: nine-year results from National Surgical Adjuvant Breast and Bowel Project B-18. J Natl Cancer Inst Monogr 2001: 96-102

Yu F, Yao H, Zhu P, Zhang X, Pan Q, Gong C, Huang Y, Hu X, Su F, Lieberman J, Song E (2007) let-7 regulates self renewal and tumorigenicity of breast cancer cells. Cell 131: 1109-1123 